\title{
Analysis of Students' Creative Thinking in Solving Arithmetic Problems
}

\author{
Lila Puspitasari ${ }^{1}$, Akhsanul In'am ${ }^{1 *}$, Mohammad Syaifuddin ${ }^{1}$ \\ ${ }^{7}$ Mathematics Department, University of Muhammadiyah Malang, INDONESIA

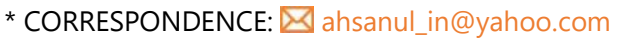

\begin{abstract}
It is aimed at analyzing students' creative thinking in solving arithmetical problems in State Junior High School 11 Malang, Indonesia. It is a qualitative approach with the type of case study where the number of the subjects were 6 students consisting of two students with high ability, two with moderate ability and two with low ability in mathematics. The results showed that the subjects under the category of high ability in mathematics did not show problems dealing with fluency, flexibility, and originality aspects, except in elaboration aspect. Students with moderate ability in mathematics still had difficulty in understanding mathematical problems, it may be seen from their steps in their less structured, detailed, and systematic solutions especially for the first problem. When they solved the problems given, their computation process was less careful, and trial and error strategies were mostly adopted in solving them. Students with low ability had difficulty in understanding the problems. Their ideas appearing in their mind were still trial and error in nature, not well structured, less systematic and detailed so that in solving and arranging the solution steps, they still encountered a lot of obstacles.
\end{abstract}

Keywords: creative, fluency, flexibility, originality, elaboration

\section{INTRODUCTION}

Anwar, Aness, and Khizar (2012) and Saragih \& Napitupulu (2015) stated that statistically, there is a significant relationship between creative thinking and students' learning achievement and its implication to the education as a whole. Therefore, it is natural to say that one of the important roles in mathematics achievement is a high-thinking level ability since it is an ability to relate, manipulate and transform knowledge and experiences that have been possessed to think critically and creatively in the effort to make decisions in solving problems in the daily life (Sari \& Yunarti, 2015; Soeyono, 2014; Supardi, 2015). Consequently, mathematics learning at school should be emphasized on developing students' creative thinking ability which is one of the characteristics in the high-thinking level. Creative thinking ability is also called creativity, that may assure the growth of mathematics as a whole (Nugraha \& Mahmudi, 2015; Nuryanti, 2016; Pehkonen, 1997; Sriraman \& Lee, 2011; Sunaryo, 2014).

Talking about learning activities at school, teachers play an important role in encouraging, growing and training students. Therefore, they should also be able to plan a learning environment supporting students' creativity (Newman, 1993; Shriki, 2010; Thomas \& Thorne 2009).

Creative learning becomes the need and objective in the education quality betterment and in students' more creative thinking ability development considered important in the education revolution (Hwang \& Chen, 2007; Tan \& Halili, 2015). Creative thinking is one of the characteristics of the high-thinking level which is a

Article History: Received 23 May 2018 • Revised 6 July $2018 \bullet$ Accepted 15 August 2018

(C) 2019 by the authors; licensee Modestum Ltd., UK. Open Access terms of the Creative Commons Attribution 4.0 International License (http://creativecommons.org/licenses/by/4.0/) apply. The license permits unrestricted use, distribution, and reproduction in any medium, on the condition that users give exact credit to the original author(s) and the source, provide a link to the Creative Commons license, and indicate if they made any changes. 
logical and divergent thinking method intended to build new ideas triggered by non-routine and challenging problems.

Creative and critical thinking in general is considered as a thinking process involving independent skills and dispositions and it has gradually been included into thinking skills. Antilogic ability, an ability to critically evaluate whether certain information may support different claims is the basic pattern for critical and creative thinking (Glassner \& Schwarz, 2007).

Sharma (2014) discusses about the effects of strategies in and anxieties with mathematics, and their interaction on students' mathematical creativity. Sharma Sansanwal Mathematic Creativity Test developed by Sharma \& Sansanwal (2012) was used as the measure of the mathematical creativity in this research, and Mathematics Anxiety Score developed by Sharma and Sansanwal (201) was employed as the measure of mathematical anxiety. The results of this research showed that strategies to develop mathematical creativity are more appropriate for students with low mathematical anxiety than those with high one after the strategies were matched with the mathematical pre-creativity response.

Another research made by Goodson, King, and Rohani (2015) developed students' higher thinking ability involving creative thinking that enables them to encounter any challenges in daily life. This research showed that the thinking ability in male students was lower than that in female ones in grade seven. On the basis of the research result on this students' thinking ability, it is proved that students need to improve their highlevel thinking ability, especially synthesis and evaluation skills needed to increase their creativity in science.

Perspective of mathematical creative thinking refers to a combination of logical and divergent thinking's on the basis of situation, but it has a conscious purpose. There are five creative thinking levels in students grade 8, from level 0 to level 4, each has different characteristics. This difference is based on fluency, flexibility, and novelty in mathematical problem solving and posing (Siswono, 2004).

Creative thinking ability should be trained and developed by the teachers in their learning activities in the classrooms. Teachers should try and use proper learning models that may grow students' creative thinking. The data analysis showed that students' creative thinking, especially in solving mathematical problems, understanding and communication, may be significantly improved (Saragih \& Napitupulu, 2015; Tan \& Halili, 2015).

Creative thinking has some stages, namely, preparation, incubation, illumination, and verification. Students' ability in creative thinking to solve mathematical problems in each stage has different attainments for each students' ability level, namely, high, low and moderate. At the preparation stage, students with high ability had been able to identify and choose information that will be used properly; those with low ability need stimulants in the form of questions.

At the incubation stage, students with high ability changed into being silent and thought how to solve the problems, those with moderate ability became silent and knew by heart how to solve the problems, while those with low ability were able to memorize patterns to solve the problems although they sometimes were hesitant. At the illumination stage, students with high ability were able to continue ideas that had been discovered before, those with moderate ability merely focused their attention on relevant information but did not exploit other ideas, then those with low ability merely focused on solving problems using the ways that had been learned before.

At the last stage namely verification, the students with high ability reviewed and tested their work before making conclusion, those with moderate ability merely reviewed their work, and those with low ability reviewed their work and made a lot of corrections in their last answer (Wulantina, 2015).

The potencies will be realized if the mathematics learning is emphasized on the high-level thinking ability requiring students to manipulate information and ideas using certain techniques on the basis of the understanding of mathematical concepts that have been recognized (Daswa, 2013; Iskandar \& Riyanti, 2015), providing them with new interpretation and implications. It is in line with the core competence that should be possessed by students in learning mathematics in Junior High School in terms of the knowledge aspect, namely understanding and applying factual, conceptual, procedural and metacognitive knowledge at the simple technical and specific level on the basis of their curiosity of science, technology, art, and culture accompanied with the insights of humanity, nationality, and statehood related to the real phenomena and events.

Creative thinking ability in mathematics is an important component that should be possessed by students dealing with their sensitiveness to mathematical problems, therefore, they will be able to consider new 
information and ideas that enable them to make relations with open mind in solving mathematical problems and daily problems encountered (Azhari, 2013; Cahyaningros, Sukestiyarno, \& Sugianto, 2013).

But in fact, a characteristic of mathematics learning in Indonesia at present is more focused on procedural ability, to solve routine problems, and still to give prominence the grade as the end result in learning. Conceptual ability is less developed, and freedom to think is still less appreciated. It may be seen from the fact that there are still many teachers who manage their class in conventional learning, one-way communication, and write students' achievement without any narration showing their learning advancement stages as a whole. This condition is supported by the results of TIMMS survey (2015) showing that the creative thinking ability in learning mathematics among the second-grade students of Junior High School in Indonesia was still below the national average grade, even that in neighboring countries, ASEAN.

On the basis of the descriptions above and of previous research results, the researchers were interested in understanding and analyzing the Junior High School Schools' thinking ability in solving mathematical problems, especially arithmetical problems requiring creativity in solving them.

\section{RESEARCH QUESTION}

How creative thinking ability among the eight grade students of State Junior High School 11 Malang, Indonesia, in solving arithmetical problems?

\section{METHOD}

\section{Approach and Type of Research}

This present research was made to analyze students' creative thinking in solving arithmetical problems. Viewed from the type of data obtained, it is a qualitative research. Meanwhile the type of present research employed is descriptive in nature. Descriptive research is a research intended to describe the existing phenomena, either natural or man-made at present or in the past. The phenomena may be in the forms of activities, characteristics, changes, relations, similarities, and differences between one phenomenon and the other (Sukmadinata, 2011). In this present research, students' creative thinking in solving arithmetical problems in State Junior High School 11 Malang, Indonesia would be described.

\section{Research Subject}

The subjects of this present research were students Grade 8 of State Junior High School 1 Malang, Indonesia. The subject consisted of 6 students, 2 students with high level ability in mathematics, using the initial S1 and S2, two students, moderate level ability in mathematics, using the initial S3 and S4, and 2 students with low level ability in mathematics initialized as S5 and S6. The data employed to determine the level of the students' ability in mathematics were the results of mid-term test in the even semester in the academic year of 2016-2017.

\section{Technique of Data Collection}

The instruments of the data collection were test and interviews. An essay test containing two contextual arithmetical problems adopted from the literacy problems in Programme Internationale for Student Assesment (PISA) was employed. PISA is used to assure the reliability and validity of the problems. The students were required to write their steps and solution alternatives in solving the problems. The results of this test were used as the basis for analyzing students' critical thinking ability. Interviews were intended to complete the obtained data. The interviews were made with six students, who were chosen some times before the students finished doing the arithmetical problems given.

\section{Technique of Data Analysis}

The qualitative data analyzed in this present research were the results of students' works in solving the arithmetical problems and the results of direct interviews with students after they finished their works. The questions in the qualitative interviews in general were unstructured and open ended in nature which are purposely made to elicit opinions or views from the respondents (Cresswell, 2010). The qualitative data would be used as the basis for the analyses of the students' creative thinking in solving arithmetical problems. 
In this present research, the results of the students' work in solving arithmetical problems would be analyzed in terms of four creative thinking aspects: fluency, flexibility, originality, and elaboration. Miles and Huberman (1992) proposed that activities in analyzing qualitative data should be made interactively and proceeded continuously until the data were saturated. The data saturation is signed by no more information or no more data that may be obtained. Activities in this data analysis involved data reduction, data display, and verification.

\section{RESEARCH RESULTS}

This section shows the analysis of the creative thinking ability of the students with high, moderate and low level abilities in solving arithmetical problems. The analysis was based on four aspects namely fluency, flexibility, originality and elaboration.

\section{The Results of the Analysis of the Creative Thinking in Students with High Ability in Mathematics}

In this present research, each student worked on problems adopted from literacy problems in PISA, in the Indonesian version. The students were not given time limit in solving the two problems and were free to solve the problems using their own ways, and were suggested to use various ways to solve them. The period of time needed by the six students to finish the problems was different. Some times after the students finished doing the problems, interviews were made to complete the needed data.

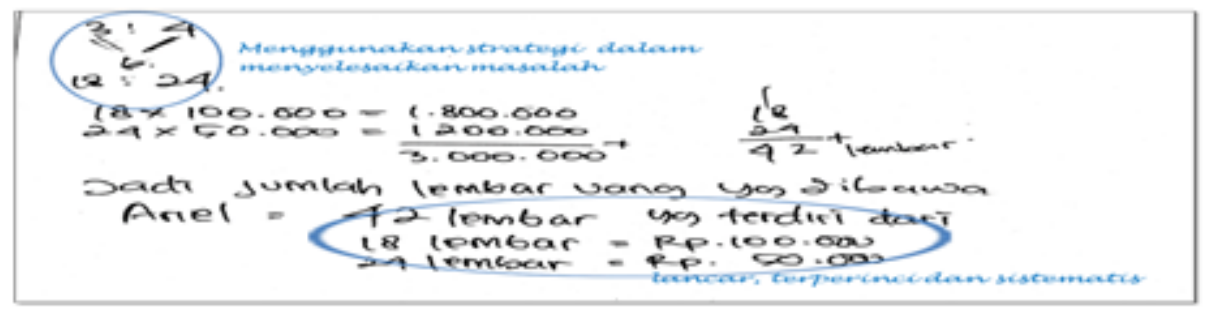

Figure 1. S1's Work Result

From S1's work result, the student could do the problem fluently since he was able to understand the problem and to determine the steps of the proper solution properly and solve it easily and correctly. During the interview, it turned out that he found another technique in solving it, but since it is too long, it is not written in the answer sheet. It can be seen from the following quotation of the interview:

\section{P1 01: Did you have another technique?}

S1 01: Yes mam, but too long.

P1 02: Can you write it?

S1 02: Yes mam!

The analysis of the work result of S2 is presented in Figure 2.

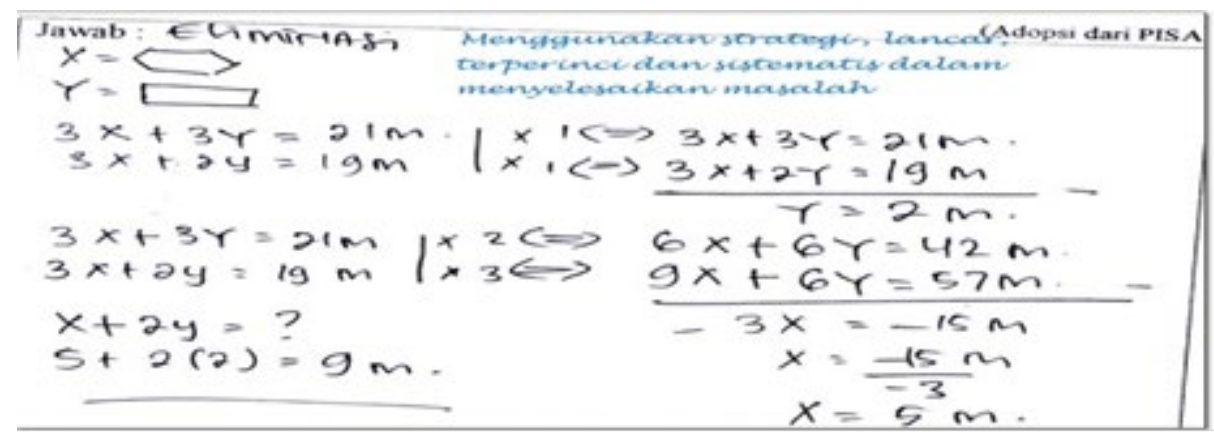

Figure 2. S2's Work Result 
From the S2's work result, it is known that the student was able to solve the problem easily. The choice of technique employed was to form an arrangement tower 1 and tower 2 into a two-variable linear equation system, giving a sign $\mathrm{X}$ for the hexagon, and $\mathrm{y}$ for the rectangular. Then he solved it using elimination and solve it correctly.

The following is another technique written by the student to do the second problem.

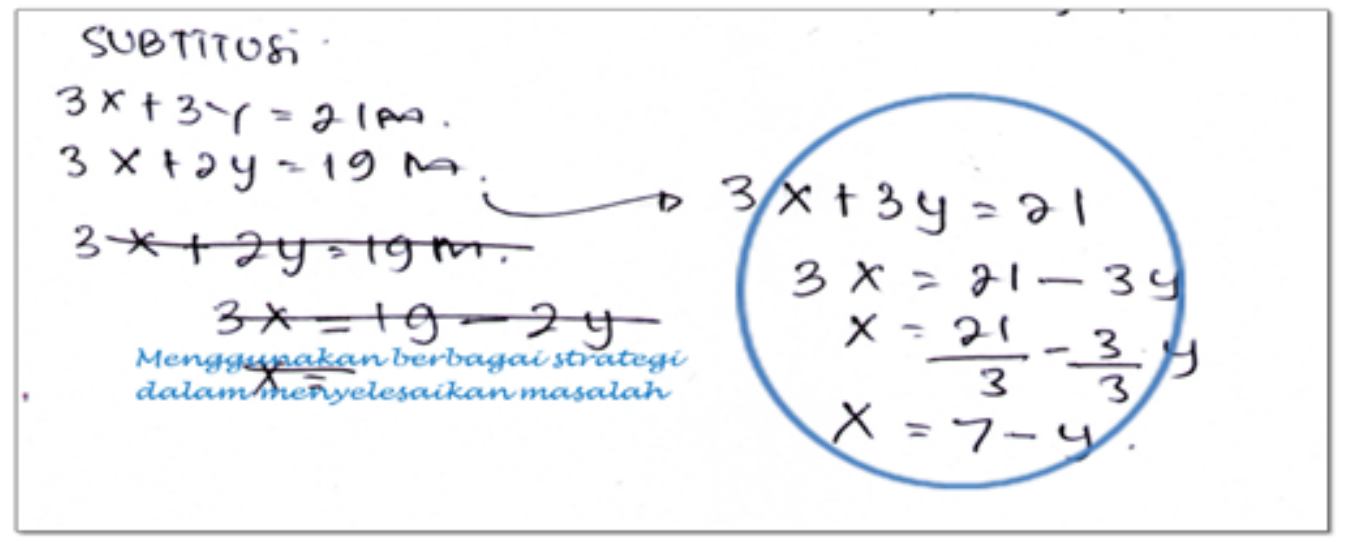

Figure 3. S2's Another Work Result

Aspect of flexibility may be seen from the student's ability in finding two techniques in solving the given problem. The second technique is different from the first, although the strategy is the same, namely using a two-variable linear equation variable. The technique chosen to solve the problem is the substitution. At first, the student had difficulty when he changed the value $\mathrm{x}$ from the second equation since the value $\mathrm{x}$ is fraction. Then the student chosen to substitute the value $x$ from the first equation which is easier. The $x$ was then substituted into the first equation, which certainly the result is not correct as expected. He realized his mistake, and substituted the value $x$ in the second equation so that the result was obtained. The value y was used to determine the value $x$, then the values $x$ and $y$ were used to determine the shortest tower height that had been written in the linear equation with $x$ and $y$ as the variables.

From the steps the students made use of in solving the problem using the first and the second techniques, it is clear that the steps are systematic and detailed. Accuracy may also be seen in each stage taken by S2, which is the ordinary technique employed by students. Therefore, no novelty element is found in the solution of the problem.

\section{The Result of the Analysis of Creative Thinking of the Students with Moderate Ability in Mathematics}

The following is presented the results of the analysis of the works of the students with low ability in mathematics in solving arithmetical problems. The result of the analysis for the first problem is as follows: 


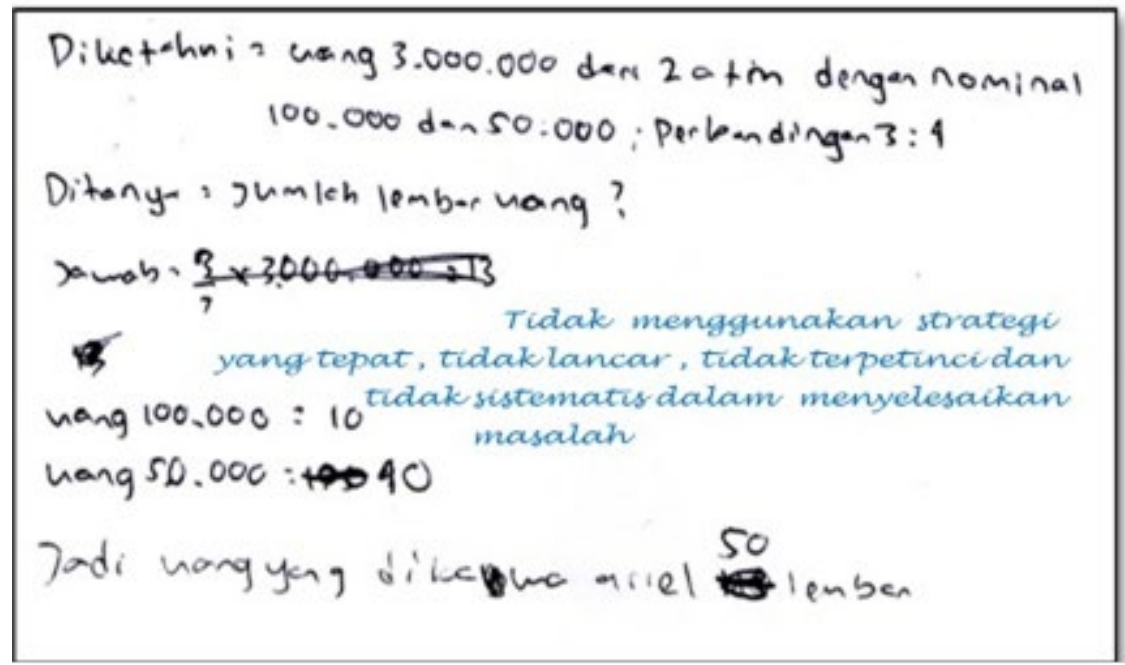

Figure 4. The S3’s Work Result

On the basis of the S3' work result for the first problem, the student seems not to do it smoothly. He was less careful in understanding the problem although he had written anything, what is known and asked in the problem. He was difficult in using the comparison for each money shards of hundreds of thousands and fifties thousands, although he had tried it. It is seen from what he has written and crossed out. At last he finished doing the problem without calculating the comparison between money shards of hundreds of thousands and fifties thousands. He merely paid attention to the nominal sum of money, namely three millions rupiah as mentioned in the problem.

The following is presented the quotation from the interviews with $\mathrm{S} 3$

P3 01: How did you finish doing this first problem?

S3 01: .... The answer is that one hundred thousand taken is 10 pieces or one million.

Five thousand taken is 40 pieces or two million. So the money brought by Ariel is 50 pieces.

P3 02: Why did you take one hundred, 10 pieces and fifty thousand, 40 pieces, what is you reason?

S3 02: By the comparison of 3:4.

P3 03: 3:4? So you got this result?

S3 03: Yes

Students' incompleteness in solving the problem may give impacts on strategies and steps used to solve the problem. The students merely guessed that if the money in the form of faction of one hundreds is taken 10 , the money shards of fifties thousands taken should be 40 to fulfill the nominal value that is asked, namely three millions. He did not involve a comparison between the sum of money shards of one hundreds thousands and fifties thousands. During the interview, the student did not realize his mistake, therefore, the flexibility aspect is not met.

It is also the case for the elaboration aspect which is not paid attention at all. Less careful in understanding the problem and also in arranging the steps of solution made the solution is not arranged systematically and in detail. It seems that the student merely focused on the nominal sum of money taken and did not pay attention to another requirement namely comparing the number of pieces of hundreds and fifties thousands. As a result, the solution is not correct and the novelty in its thought is invisible. S4's work result is presented in Figure 5. 


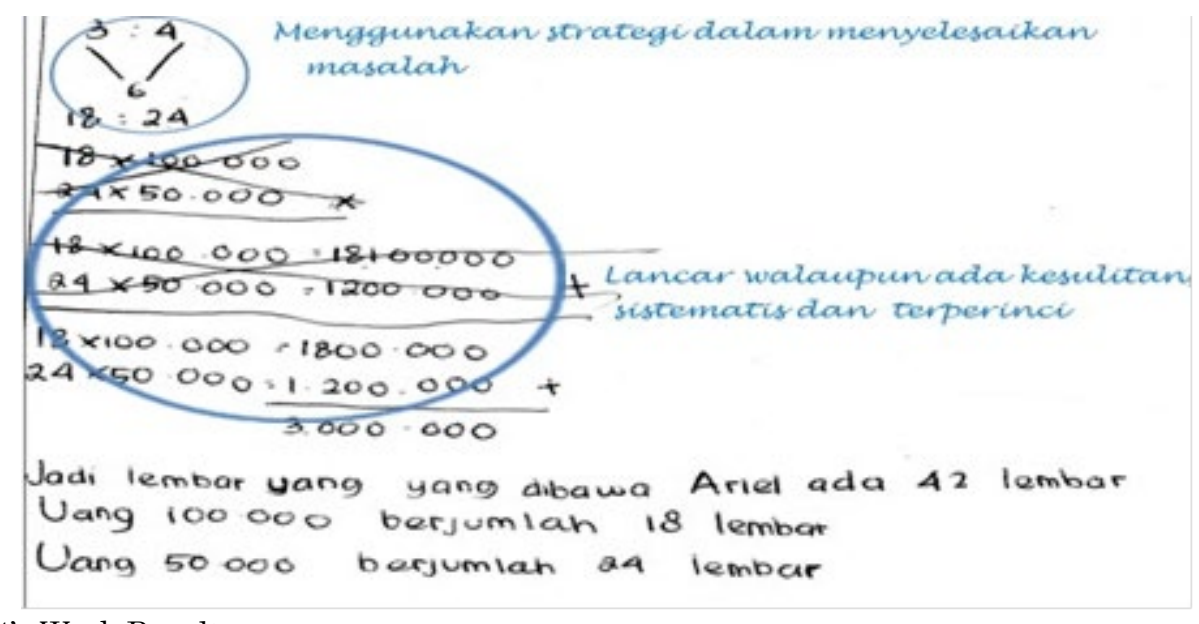

Figure 5. S4's Work Result

On the basis of the S4's work result of the first problem, the student could work on the problem fluently although at first he had some difficulties. At first, he tried to multiply each comparison number with six and then checked the result. During the checking, the calculation was incorrect, but at last he could solve the problem correctly.

According to the interview, he got confused with the determination of what step to take to solve the problem. The following is the citation of the interview with him supporting the statement.

P4 01: How did you solve the first problem?

S4 01: First I tried it with comparison mam, but I can't got it. I was confused with other ways, yeah... I tried and tried to multiply with 6 , the result is then three millions. $\quad$ Luckily, I found it, three to four if equally multiplied with 6 equals with 18 to $24 \ldots$.

P4 02: Now there are some crosses, why?

S4 02: Yeah, I was wrong to write the sign + and its line in the addition.

(The students did not realize that actually the mistake is in the calculation)

\section{The Results of the Analysis of the Creative Thinking of the Student with Low Ability in Mathematics}

On the basis of the S5's work result for the first problem, the student did not understand the problem in question so that he could not solve the problem fluently and did not give the correct answer. He merely took some pieces of money shards of hundreds thousands from ATM 1 and the money shards of fifties thousands from ATM 2, then he added it up so that the result is three millions. The quotation of the following interview explains his way of thinking.

P5 01: Ok, now what you wrote here for ATM 1 is that you took 15 pieces and ATM2 30 pieces. Why did you take 15 and 30 ?

S5 01: To make it five hundred thousands.

P5 02: ... how did you think it?

S5 02: Added it up.

P5 03: "Merely added it up, in your opinion is the addition correct?"

S5 03: Correct. 


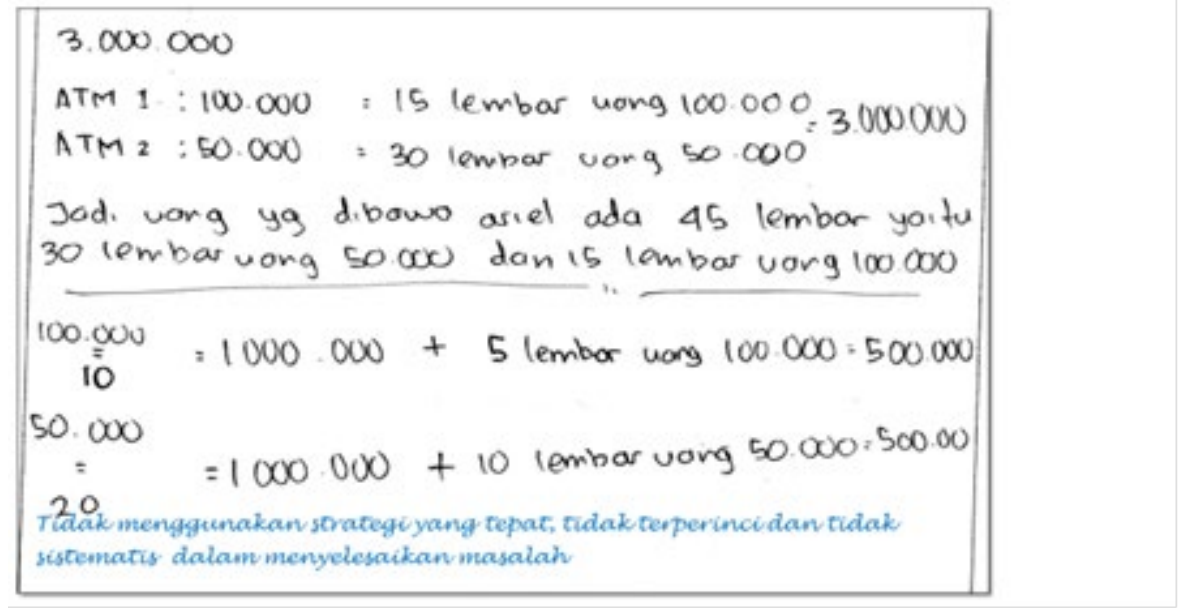

Figure 6. S5's Work Result

The strategy made by the student to solve the problem seems not to be in detail and systematic so that the elaboration aspect is not fulfilled. When the student took a number of pieces of money from ATM 1 and ATM2, he did not pay attention to the comparison made for the problem. It is shown in the interview, as shown below:

P5 04: Here, at the written problem, there is a comparison three to four

Didn't you think it about?

S5 04: No.

P5 05: So, what is important is the nominal sum of money of three million?

S5 05: Yes, mam.

The students merely took the money shards of 15 pieces of hundreds of thousands from ATM 1, and then multiplied it to find the nominal sum of the money. Then, he took the rest of the nominal sum of money that should be taken from ATM 2 containing the money shards of fifties thousands with the amount of 30 pieces. It is added up, and the result is three millions rupiahs, but it is not being asked for, but there is a requirement for the comparison of the number of money shards of hundreds and fifties thousands, namely 3:4. The student did not think it about when he worked on the problem. He merely used one way to solve the problem, so it means that the flexibility aspect in thinking is not fulfilled. The novelty aspect may also not emerge in the student's work result. If it is a trial-and-error, it must be often made by other students in working on the type of problem.

Then for the S6's work results as presented in Figure 7, the student could not solve the problem correctly. He did not pay attention and did not involve the comparison of the number of the money shards of hundreds and fifties thousands that would be taken in solving the problem. He merely focused on the number of the nominal money taken, namely three million. He did not make any systematic and detailed steps and did not try to use another way in solving the problem. The result of the following interview represents the students' way of thinking:

P6 01: How did you solve this first problem?

S6 01: The sum of money that should be taken is three millions, while the nominal money is hundreds and fifties thousands with the comparison of 3:4. So hundreds thousands is 20 pieces, so the result is two millions, from the comparison of 3:4. The fifties hundreds is 20 pieces, it is one million. So, the hundred thousand is two million and fifties thousands, one million. So the number of pieces of money ...."

P6 02: Did you consider the comparison of $3: 4$ that is known?

S6 02: Yes

P6 03: Did you have another way, beside this?

S6 03: No. 


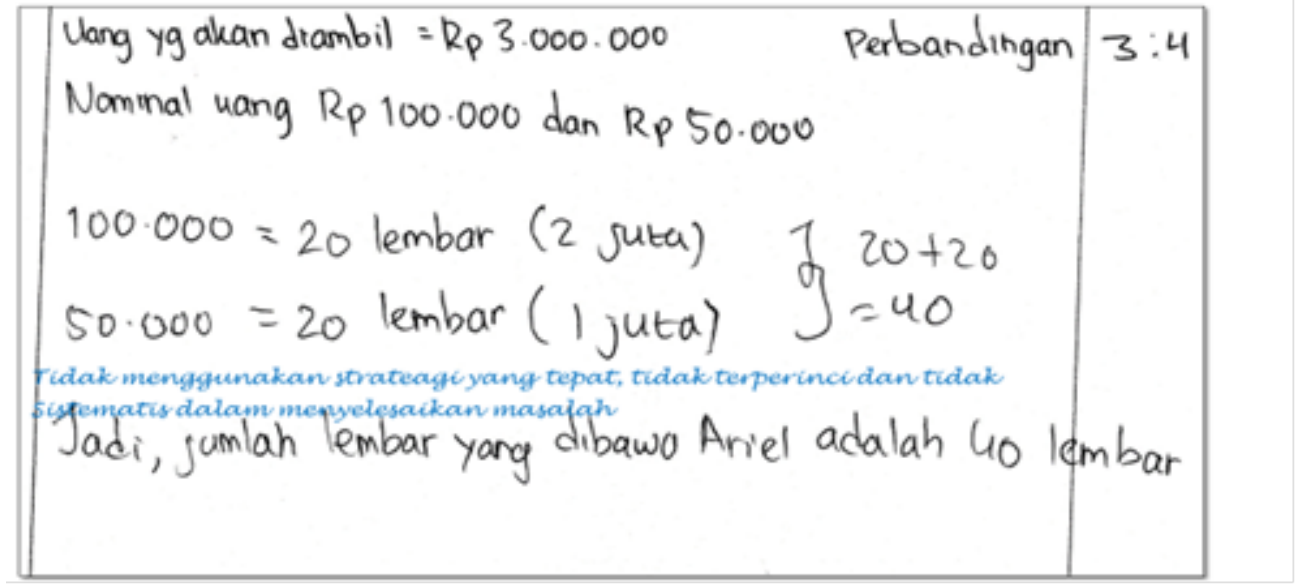

Figure 7. S6’s Work Result

From the results of the interviews and student's work, it seems that the student has tried to understand, to make easy rules, and make steps in solving the problem. Although at first the student just guessed it, as shown by the crosses, but at last he found out the proper rules and could solve the problem correctly.

\section{DISCUSSION}

Creative thinking needs some sensitivity to the problem encountered, the consideration of the given information, making some relations, the determination of the steps of solution, and the application of imagination to raise different new ideas. When being given the non-routine arithmetical problems, the six research subjects gave different responses to the problem. Viewed from their ways of thinking, there is a similarity, they started working on the problem with understanding and describing it, making a plan of solving it based on their mathematical ability, and then they started to think about other alternatives to solve the problem.

According to Siswono (2004), creative thinking in mathematics needs ability to solve any problem fluently, in detail, systematically, to give various and correct solutions, and to find out a solution which is "extraordinarily" made by the student at his level of knowledge. The student's work result may be said to be extraordinary if it seems different and does not follow a certain pattern.

This research result is in line with that made by Anwar, et al (20120 stating that there is a significant correlation between students' creative thinking and their learning achievement. This research is also supported by Saragih and Napitupulu's (2015) research that students' academic achievement may be predicted from their creativity ability.

Creative thinking starts from the emergence of preliminary ideas after understanding a problem. The emergent ideas really determine the steps in solving the problem. In this present research, students with high ability in mathematics succeed in understanding problems, bringing up ideas, and making steps in solving the problem. They can solve problems fluently and systematically and also in a detailed, and structured manner, and they may use some strategies of solutions.

Students with moderate ability in mathematics have some difficulties in understanding problems. They are rather difficult in raising ideas and making solutions in a detailed, structured and systematic manner especially the first problem, but they solved the second problem fluently.

Students with low ability in mathematics seem to have some difficulties in understanding problems. Their ideas in making steps of the solution are trial-and-error in nature. They do not make use of clear rules and manners. They were also difficult in determining strategies of solving problems.

The research result is in line with that of Siswono's (2004) stating that the ability in synthesizing ideas, building ideas and then planning the application of ideas are different for each level of students' ability. 


\section{CONCLUSION}

Dealing with the category of Subject S1 and S2, they did not have any difficulties in understanding the problems given. Their emergent preliminary ideas were proven by making steps of solving problems using their various strategies. They did not have much problems in solving the problems, they are fluent and careful in soling them where their steps and strategies are structured, detailed and systematic. The fluency, flexibility, and elaboration elements may be fulfilled, but no new strategies have arisen so the novelty element has not been met. The criterion of creative thinking reached by the students with high ability in mathematics is creative enough.

Students with moderate ability in mathematics S3 and S4 were still difficult in understanding the problems given so that the steps of the solution are less structured, less detailed and less systematic, especially for the first problem. When solving the problem, the students were less careful in their calculations, and the strategies they employed were also trial-and-error in nature. Although the trial-and-error is allowed in solving a problem, but it reflects the ideas in students' thought. The fluency and elaboration elements are fulfilled, but the flexibility and originality in the problem solving have not appeared yet. The criterion of creative thinking reached by the students with low ability in mathematics is less creative.

Students with low ability in mathematics namely S5 and S6 had difficulty in understanding the problems. Their ideas still tended to the trial-and-error fashion, were less structured, less systematic and less detailed so that in solving and making steps of the solution they still encountered many obstacles. The indicator of creative thinking has not emerged yet in the students with low ability in mathematics. The criterion of creative thinking reached by these students is not creative.

\section{Disclosure statement}

No potential conflict of interest was reported by the authors.

\section{Notes on contributors}

Lila Puspitasari - Mathematics Department, University of Muhammadiyah Malang, Indonesia.

Akhsanul In'am - Mathematics Department, University of Muhammadiyah Malang, Indonesia.

Mohammad Syaifuddin - Mathematics Department, University of Muhammadiyah Malang, Indonesia.

\section{REFERENCES}

Anwar, N. M., Aness, M., \& Khizar, A. (2012). Relationship of Creative Thinking with Academic Achievements of Secondary School Students. International Interdisciplinary Journal of Education, 1(3), 12-24.

Azhari. (2013). Peningkatan Kemampuan Berpikir Kreatif Matematika Siswa Melalui Pendekatan Kontruktivisme Di Kelas VII Sekolah Menengah Pertama (SMP) Negeri 2 Banyumas III. Jurnal Pendidikan Matematika.

Cahyaningros, M. I., Sukestiyarno, S., \& Sugianto, S. (2013). Pembentukan Karakter Dan Berpikir Kritis Menggunakan Teori Konstruktivisme Dengan Pendekatan Inkuiri Materi Trigonometri. Unnes Journal of Mathematics Education Research.

Creswell, J. W. (2010). Research Design: Pendekatan Kualitatif, Kuantitatif, dan Mixes (Edisi ke 3). Yogyakarta: Pustaka Pelajar.

Daswa. (2013). Penerapan Model Pembelajaran Sinektik Untuk Meningkatkan Kemampuan Berpikir Kreatif Dan Komunikasi Matematis Siswa Madrasah Tsanawiyah. Universitas Pendidikan Indonesia > Sekolah Pasca Sarjana > Pendidikan Matematika S-2.

Emzir. (2010). Metodologi Penelitian Kualitatif: Analisis Data. Jakarta: Raja Grafindo.

Glassner, A., \& Schwarz, B. B. (2007). What stands and develops between creative and critical thinking?. Argumentatin? Journal Articles; Reports - Research ISSN-1871-1871. https://doi.org/10.1016/j.tsc.2006. 10.001

Goodson, L, FJ. King, \& Rohani, F. (2015). Improving student's higher-order thinking competencies, including critical evaluation, creative thinking, and reflection on their own thinking. (Level, Declarative Knowledge, Plan, Quality Enhancement), Research in Science Education. 
Hudojo, H. (1998). Mengajar Belajar Matematika. Jakarta: Depdikbud.

Ikhsan, M., \& Rizal, S. (2014). Penerapan Model Pembelajaran Berbasis Masalah untuk Meningkatkan Kemampuan Berpikir Kritis dan Disposisi Matematis Siswa. Penerapan Model Pembelajaran Berbasis Maslalah Untuk Meningkatkan Kemampuan Berpikir Kritis Dan Disporsisi Matematis Siswa. http://doi.org/10.1039/b908937c

Indiastuti, F. (2016). Pengembangan Perangkat Model Discovery Learning Berpendekatan Saintifik untuk Meningkatkan Berpikir Kreatif dan Rasa Ingin Tahu. Jurnal Pendidikan Matematika.

Iskandar, J., \& Riyanti, R. (2015). Upaya Meningkatkan Kemampuan Berpikir Kreatif Siswa SMP Dengan Pendekatan Matematika Realistik Indonesia. In seminar Nasional Matematika dan Pendidikan Matematika UNY.

Ismaimuza, D. (2013). Kemampuan berpikir kritis dan kreatif matematis siswa smp melalui pembelajaran berbasis masalah dengan strategi konflik kognitif. Jurnal Teknologi (Sciences and Engineering). http://doi.org/10.11113/jt.v63.2002

Johnson, B. E. (2006). Contextual Teaching \& Learning, terj. Ibnu Setiawan. Bandung: MLC.

Kirkley, J. (2003). Principle for Teaching Problem Solving Technical Paper \#4. Indiana University, Plato Learning.

Miles, M. B., \& Huberman, A. M. (1992). Analisis Data kuantitatif: Buku Sumber tentang Metode-metode Baru. Jakarta: UI Press.

Moleong, L. J. (2002). Metodologi penelitian kualitatif. Bandung: Remaja Rosdakarya.

Munandar, U. (1999). Kreativitas dan keberbakatan. Jakarta: Gramedia Pustaka Utama.

Munandar, U. (2009). Pengembangan Kreativitas Anak Berbakat. Jakarta: Rineka Cipta.

NCTM. (2000). Principles and Standarts for School Mathematics. Reston, VA: NCTM.

Newman, F. M., \& W. G. (1993). Five standaars for authentic instruction. Educational Leadership, 50, 87.

Noer, S. H. (2007). Pembelajaran Open-Ended untuk Meningkatan Kemampuan Pemecahan Masalah Matematik dan Kemampuan Berpikir Kreatif (Penelitian Eksperimen pada Siswa Salah Satu SMP N di Bandar Lampung). Tesis Sps UPI: Tidak Diterbitkan.

Noer, S. H. (2011). Kemampuan Berpikir Kreatif Matemtis Dan Pembelajaran Matematika Berbasis Masalah Open-Ended. Jurnal Pendidikan Matematika, 5(1).

Nugraha, T. S., \& Mahmudi, A. (2015). Keefektifan Pembelajaran Berbasis Masalah dan Problem Posing Ditinjau dari Kemampuan Berpikir Logis dan Kritis. Jurnal Riset Pendidikan Matematika. https://doi.org/10.21831/jrpm.v2i1.7154

Nuryanti, M. (2016). Peningkatan Kemampuan Komunikasi Dan Berpikir Kritis Matematis Melalui Model Kooperatif Stad Dan Murder. Jurnal Pengajaran MIPA. http://doi.org/10.18269/JPMIPA.V21I1.654

Pehkonen, E. (1997). The State-of-Art in Mathematical Creativity. Number 3 Electronic Edition ISSN 1615679x. https://doi.org/10.1007/s11858-997-0001-z

Polya, G. (1973). How To Solve It: A New Aspect of Mathematical Method (ed 2). Princeton, New Jersey: Princeton University Press.

Sabandar, J. (2005). Pertanyaan Tantangan dalam Memunculkan Berpikir Kritis dan Kreatif dalam Pembelajaran Matematika. Makalah disajikan dalam MIPA-JICA.

Saragih, S., \& Napitupulu, E. (2015). Developing Student-Centeres Learning Model to Improve High Order Mathematical Thinking Ability. Canadian Center of Science and Education, 8, 104-112.

Sari, I. P., \& Yunarti, T. (2015). Open-ended Problems untuk Mengembangkan Kemampuan Berpikir Kreatif Siswa. In Seminar Nasional Matematika dan Pendidikan Matematika UNY.

Semiawan, C. R. (2009). Memupuk Bakal dan Kreativitas Siswa Sekolah Menengah. Jakarta: Gramedia.

Sharma, Y. (2014). The Effects of Strategy and Mathematics Anxiety on Mathematical Creativity of School Students, Ramgarhia College of Education, Phagwara, Punjab, India. Mathematics Education, 9(1), 2537.

Sharma, Y., \& Sansanwal, D. (2011). Construction of a standardized scale for measuring mathematics anxiety in school children. Experiments in Education, XXXIX(1), 31-32.

Sharma, Y., \& Sansanwal, D. (2012). Development and standardization of mathematical creativity test. The Mathematics Education, XLVI(4). 
Shriki, A. (2010). Working like real mathematicians: developing prospective teacher's awareness of mathematical creativity through generating new concepts. Educational Studies in Mathematics. https://doi.org/10.1007/s10649-009-9212-2

Silver, E. (1997). Fostering Creativity through Instruction Rich in Mathematical Solving and Problem Posting.

Siswono, T. Y. (2004). Identifiying Creative Thinking Process of Students through Mathematics Problem Posing. Bandung Islamic University: Proceeding of the International Conference on Statistics and Mathematics and Its Application in the Development of Science and Technology.

Soeyono, Y. (2014). Pengembangan Bahan Ajar Matematika dengan Pendekatan Open-ended untuk Meningkatkan Kemampuan Berpikir Kritis dan Kreatif Siswa SMA. PYTHAGORAS: Jurnal Pendidikan Matematika.

Sriraman, B. (2004). The Characteristi of Mathematical Creativity. The Mathematics Educators, 14(1), $19-34$.

Sriraman, B., \& Lee, K. H. (2011). The Elements of Creativity and Giftedness in Mathematics. Rotterdam: Sense Publisher. https://doi.org/10.1007/978-94-6091-439-3

Sukmadinata, N. S. (2011). Metode Penelitian Pendidikan. Cetakan ke 7. Bandung: Remaja Rosdakarya.

Sumarmo, U., \& Dedy, E. R. (1994). Suatu Alternatif Pengajaran untuk Meningkatkan Pemecahan Masalah Matematika pada Guru dan Siswa SMA. Bandung: Laporan Hasil Penelitian FPMIPA IKIP Bandung.

Sunaryo, Y. (2014). Model Pembelajaran Berbasis Masalah Untuk Meningkatkan Kemampuan Berpikir Kritis Dan Kreatif Matematika Siswa SMA Di Kota Tasikmalaya. Jurnal Pendidikan Dan Keguruan. http://doi.org/10.1007/s13398-014-0173-7.2

Supardi. (2015). Peran Berpikir Kreatif Dalam Proses. Jurnal Formatif.

Suryadi, D., \& Herman, T. (2008). Eksplorasi Matematika Pembelajaran Pemecahan Masalah. Jakarta: Karya Duta Wahana.

Tan, S. Y., \& Halili, S. H. (2015). Effective Teaching of Higher-Order Thinking (HOT) in Education. The Online Journal of Distance Education and e-Learning.

Thomas, A., \& Thorne, G. (2009). How to Increase Higher Order Thinking. Metarie, LA: Center for Development and Learning.

TIMMS. (2015). International Results in Mathematics. USA: TIMSS \& PRILS International Study Center.

Wena, M. (2013). Strategi Pembelajaran Inovatif Kontemporer: Suatu Tinjauan Konseptual Operasional. Jakarta: Bumi Aksara.

Wulantina, E., T. A. K. \& R. (2015). Proses Berpikir Kreatif Siswa dalam Pemecahan Masalah Matematika Ditinjau dari Kemampuan Matematika pada Siswa Kelas X MIA SMAN 6 Surakarta. Jurnal Elektronik Pembelajaran Matematika ISSN: 2339-1685, 3(6). 